\title{
1. Introduction to the Research Handbook on Modern Legal Realism
}

\author{
Shauhin Talesh, Elizabeth Mertz and Heinz Klug
}

The landscape of legal and social science scholarship has changed dramatically in the past twenty-five years. In particular, empirical research is now fully embedded in the legal academy. Many legal academics still focus primarily on legal doctrine and texts of judicial opinions, perform analyses assuming that court decisions automatically cause real change on the ground, and opine about understandings of law and legal doctrine using a normative framework. Traditional doctrinal exploration will always remain embedded in how legal academics approach legal questions. But the past twenty-five years have seen a surge of empirical scholarship in the legal academy and rising interest in a broader exploration of law's impact in society. There is an increased appetite for going beyond pronouncing what the law ought to be and instead, uncovering what's actually going on with law in the world, including the role of lawyers. This is accompanied by an increase in the number of law faculty with JD and $\mathrm{PhD}$ degrees as well as by growth in legal academics taking classes on empirical methods to bolster their ability to engage in empirical research. Whereas law review journals used to be a location for doctrinal scholarship only, we now see some law journals publishing empirical research.

The explosion of empirical research in the legal academy is housed in two emerging movements: new Legal Realism (NLR) and empirical legal studies (ELS). ${ }^{1}$ This new or renewed focus on empirical studies of law in the legal academy is less about its method or subject matter than it is about the intellectual agenda and institutional location. NLR and ELS are movements that try to "legitimate empirical research within the legal academy itself" (Suchman \& Mertz 2010, 556). Although the methods used are consistent with how prior interdisciplinary scholars have approached law-related questions, ELS and NLR frame themselves differently from what has come before.

In fact, both NLR and ELS consider themselves logical outgrowths from the original Legal Realist movement that took place in the early twentieth century (Heise 2002; Macaulay 2005). The old Legal Realists were a group of scholars who sought to pivot away from doctrinal analysis and legal formalism toward nudging legal scholars and lawyers to think about how social context affects the delivery of law on the ground. Their pragmatic, realistic approach considered politics, policy, and the law in action within and among communities, as well as actively wrestling with how real-world pressures beyond doctrine impact judicial decision-making. The old Legal Realists encouraged the use of empirical methods and social

\footnotetext{
To be clear, many scholars outside the legal academy have been pursuing empirical work on law for a very long time. The work of Durkheim (1893), Weber (1922), Malinowski (1959) and others laid an early foundation for interdisciplinary research in the law-and-society movement and a variety of social science disciplinary sub-specialties such as judicial politics, legal history, legal anthropology, the Sociology of Law, and law-and-economics. While it is only now starting to receive deserved recognition, the work of W.E.B. Du Bois (1899) also provided crucial early insights into crime and justice.
} 


\section{Research handbook on modern Legal Realism}

science perspectives to influence and inform thinking about the law (Schlegel 1995). Although the insights of Charles Clark, Karl Llewellyn, Louis Brandeis and other realists were broadly accepted, the movement never permanently cemented itself in law schools or in the way legal scholars approach legal questions and implement legal education. Doctrinal-based, normative approaches continued to prevail in the legal academy as the dominant mode of scholarship and reasoning, rather than empirically driven research.

NLR and ELS both share the old Legal Realist desire to move beyond traditional doctrinal scholarship. They also share a desire for collecting data on what is actually happening on the ground to better inform legal and policy debates. In this respect, they share common ancestry and there is some overlap within and among the professional communities. But these two movements are very different in style and substance and reflect distinctly different approaches to empirical approaches to law.

Like many movements, ELS does not have a single, canonical self-definition. And, in fact, some ELS scholars have strong ties with the law-and-society movement and have participated in NLR as well. However, in general, ELS frames itself as producing "legally sophisticated empirical analysts [that] help inform litigants, policymakers, and society as a whole about how the legal system works" (Eisenberg 2004, 1741). Other scholars define ELS more narrowly as constituting research around quantitative methods and hypothesis testing (George 2006). The vast majority of scholarship in the vein of ELS is limited to quantitative work and hypothesis testing. While some early ELS founders were also participants in the law-and-society movement, ELS itself moved away from those roots to found a separate journal and association, and is largely a law school movement. That is, ELS participants often work at law schools, have a JD and $\mathrm{PhD}$, attend law school-based institutes and gatherings, and produce scholarship in law-school based journals or peer-review journals with heavy influence from law faculty. ELS proponents often encourage law faculty to gain training in quantitative methods, and seek collaboration from social scientists with sophisticated training. The primary contributing disciplines from the social sciences are economics, political science, and psychology. ELS's methodological vision is "more quantitative than qualitative, more confirmatory than exploratory, and more contemporary than historical" (Suchman and Mertz 2010, 558).

In particular, neo-institutional economists, political scientists studying judicial politics and behavior, social psychologists and behavioral economists, and quantitatively inclined law professors are the scholars that attend ELS gatherings. While there are notable exceptions within the group of ELS scholars, the movement in general turns to a limited number of social science disciplines as a source of technical skills that can be brought into established legal endeavors. The unifying force for these scholars is that they use empirical methods to study legal questions. ELS sees legal doctrine as providing questions to be tested empirically. With the exception of some who are more grounded in their social science disciplines than are their law school-oriented compatriots, ELS scholars rarely pose questions in a theoretically grounded way. Instead, ELS frames questions around the legal academy's traditional constituencies and often highlights how a particular study is useful to practicing lawyers, legislators, and judges. ELS also tends to avoid disciplinary debates that legal audiences would likely feel are too obtuse.

In contrast, NLR's distinctive qualities include multi- and interdisciplinarity, an openness to multiple methods, and a clear acknowledgment of the importance of theory in law and social science. That is, new Legal Realists are committed to maintaining rigorous standards, balancing theory and empirics, being methodologically diverse, and maintaining the proper 
balance and scholarly distance while also producing empirical research that impacts policy innovations. NLR is much more closely aligned with the inclusive interdisciplinary approach of the law-and-society movement. In particular, NLR emphasizes the social context of law and seeks to develop approaches that account for how law actually works in action. Considered a much "bigger tent", NLR embraces the full range of social sciences as opposed to a single social science field. The NLR movement attempts to develop a highly integrative model for studying law that uses multiple methodologies. Rather than relying on statistical models alone, NLR scholars try to engage with the social world more directly at multiple levels and in multiple ways. In this respect, NLR mirrors more closely the old Legal Realist's openness to a wide range of social science methods and theories. NLR focuses on the effect of law on the everyday lives of ordinary people, the experiences of professionals and elites, and the impact of legal doctrine.

As opposed to preferring one method, the methods used by NLR scholars are driven by theoretically informed questions about law, although those questions are also formulated with law's internal logic in mind. The "big tent" NLR scholars believe that consulting both statistical analyses and field-intensive methods such as participant observation and interviewing results in research that, taken together, gives a fuller and more accurate understanding of law in social context and in action. Moreover, new Legal Realist approaches pay close attention to the process of translation between and among law and various forms of empirical research. We view translation as crucial because it creates a space for social scientists and lawyers to recognize and respect the complex interactions required in order to combine (with any rigor) various empirical approaches to understanding law; the institutional and normative dimensions of law in action; the "internal" views of law as doctrine, as well as from legal philosophy; and the lawyers' understandings of law as procedure and practice. In discussing the interdisciplinary translation process as a core mission of new Legal Realism, Christopher Tomlins notes that NLR develops

a sophisticated process of translation and exchange between law and social science. In this translation process, the goal is to create a positive agenda, building from but not ending with critique, through which the best learning from the social sciences can be brought to bear on legal problems without losing the nuances and priorities of either field (Tomlins 2006, 795).

New Legal Realism also combines bottom-up and top-down perspectives in order to provide a more holistic explanation of law and society. Whereas law-and-society scholarship focuses on the social science of law, NLR focuses on how to translate that to law and lawyers.

In some respects, ELS and NLR are two empirical cruise ships, each with different amenities, passing each other in the legal academy ocean of scholarly discourse. ELS is the more well-known and popular ship within the US legal academy. However, the passengers on this ship are predominately quantitative empirical scholars focused on definitive hypothesis testing, topical immediacy, and theoretical training in law-and-economics and law and psychology. ELS is a smaller, faster, leaner ship that has caught the eye of many people as it sails by. NLR's ship is much bigger and roomier, and therefore holds far more passengers that bring a wider variety of empirical tools and theoretical frames. The greater diversity of scholarly frames and approaches allows more room for cross-fertilization and diversity among a wide variety of social science perspectives. However, the NLR is not as well-known or flashy and consequently, has not garnered as much attention within conventional law school circles in 
the US, though NLR has gained prominence in academic communities in Europe. At the same time, NLR also welcomes passengers from ELS, because there is room for their approach.

The goal of this volume is to show the distinctive qualities of New Legal Realism and to capture where it stands around its fifteenth anniversary. In doing so, we demonstrate both NLR's fruitful continuation of the Legal Realist adventure - reaching beyond national boundaries to form international conversations, based heavily on law-and-society networks and traditions. In addition, we provide a contrast to ELS. The NLR project clearly visible in this volume does not just use social science methods to address problems relating to lawyers and traditional legal institutions, but includes many chapters by social scientists using social science theory and methods to understand law across a variety of subject areas such as immigration, policing, and globalization. Moreover, the book also includes chapters by a number of law professors using social science methods to address legal problems in a variety of areas. In addition, it offers a series of chapters from scholars - across law and social science - explaining what they think particular disciplinary approaches offer to the process of translating law and empirical research. Thus, we hope this book encompasses the best of the new Legal Realist ideals - and in particular a desire for interdisciplinary communication and translation that accounts for the theories, methods, and central questions of both law and the social sciences.

A wide range of scholars both in law schools and social science departments contributed to this volume. In their contributions we can see signature aspects of NLR - aspects that also crystallize the important distinctions between NLR and ELS: a multi- and interdisciplinary scholarly approach, methodological diversity, and a commitment to theoretically-informed empirical research along with care in translating that research. We very briefly highlight these distinctions at the outset in order to provide a guide for some of the pressing issues.

\section{NEW LEGAL REALISM AND EMPIRICAL LEGAL STUDIES: A CONTRAST}

One of NLR's greatest strengths is its inclusive approach toward methodology. Although both NLR and ELS profess to be empirical, NLR resists the temptation to categorize empirical work as solely quantitative and seeking causal inferences. NLR conceptualizes empirical research broadly, in keeping with its multi- and interdisciplinary approach. From this vantage point, empirical research encompasses "any systematic, observational study of law", regardless of whether the observations are quantitative or qualitative, direct or archival, historical or contemporary (Suchman and Mertz 2010, 563). Moreover, the purpose of research can be exploratory or confirmatory, abstract or applied, descriptive or prescriptive. NLR's emphasis on interpretative and qualitative methods, legal discourse and meaning, and sensitivity to institutional context adds rigor to many of the legal problems that law professors study.

In addition, ELS uses microeconomic or behavioral methods to identify the non-legal independent variables causing or determining law defined as a dependent variable. Under this approach, law has relatively little power and there is a focus on independent, intervening extra-legal factors. Conversely, NLR tends to encompass a wide variety of approaches that recognize that law itself - as language, discourse, institutional practices, and as a source for intermediation and aspirational ideals - is interrelated with other facets of mutually constitutive power. Law is viewed as relational, contextual, contingent, or process-based. Moreover, law is seen as both an independent and dependent variable. A more multi-dimensional con- 
ception of law is possible because of the much broader participation by scholars from multiple disciplines beyond (but including) those that rely on quantification. This volume consists of chapters from authors whose training is derived from a wide variety of disciplines that use a wide variety of methods to explore legal questions and problems. The chapters focus not just on what the law is but how law matters.

The chapters in this volume also highlight another strength of NLR research: a commitment to research questions informed by theory. This is a key distinction between ELS and NLR. ELS tends to focus on data and little theory - or theory that is presumed rather than directly addressed. ${ }^{2}$ Rarely does theory motivate the research question. A major focus of the ELS's flagship journal, the Journal of Empirical Legal Studies, is on what affects the legal system or the impacts of the legal system - and especially on instrumental behavior. The reality is that social science does not often yield clear and certain answers to normative questions. Law, like society, must be put into context. NLR embraces qualitative and quantitative methods and therefore focuses more attention on background theories and assumptions regarding how to translate between different kinds of social science understandings of law in social context. NLR integrates theory, analytical premises and empirical data as opposed to allowing a focus on the type of data to guide the entire investigation.

While empirical work is a major approach to scholarly discourse in law schools and has achieved a certain level of normalization, many empirical legal scholars have not devoted sufficient attention to the process of translating between social science and law. Empirical findings are not necessarily easily adaptable to the normative field of law - a field that has its own language and expertise. Moreover, social science researchers generally deploy their methods in the context of theories that have motivated a particular research question and therefore, provide important contexts within which to recognize the limits of what the social science method can achieve. We are cautious of applying social science methods to legal problems with no consideration of the theoretical frames and contexts that give those methods meaning. The chapters in this volume have an attentive eye toward research questions grounded in theory.

There are other distinctions between NLR and ELS, but we think NLR's multi- and interdisciplinary scholarly approach, methodological diversity, and commitment to theoretically-informed empirical research (while always attending to the process of interdisciplinary translation) are some of the vital differences. We invite you to keep these and other distinctions in mind as you review this volume, and assess how NLR is different from ELS, old Legal Realism, and even law-and-society. At the same time, we hope you will see the strong connections between NLR and the broader realist tradition, as well as its continuing allegiance to the law-and-society tradition. ${ }^{3}$

\footnotetext{
2 This is a broad generalization and omits the many scholars who bridge ELS and NLR, or ELS and law-and-society, and who tend to be more cognizant of, and guided by, theory.

3 For example, by contrast with both ELS and the Law and Humanities movement, NLR has not tried to start its own journal or hold its own annual meetings. In the US, NLR scholars gather primarily at the Law \& Society Association annual meetings, and they publish in the journals commonly read by law-and-society scholars - although they also publish in law reviews read by legal scholars. Unlike those in ELS, NLR scholars do not (mis)-use the word "empirical" to mean only quantitative research.
} 


\section{NEW LEGAL REALISM, SOCIOLEGAL STUDIES, AND THE REALIST TRADITION}

Another key aspect of NLR is its position vis-à-vis the law-and-society tradition. By contrast with some other groups that sought to separate from the organized Law \& Society Association (LSA), NLR is explicitly committed to staying embedded within that group. The main distinction between LSA and NLR is that, as Michael McCann has summarized it:

NLR is self-consciously the ambassador to contemporary law schools for a tradition of law-and-society scholarship that has itself expanded dramatically in recent decades to include diverse interpretive as well as behavioral research, qualitative as well as quantitative research methods, and a host of critical theoretical frameworks applied to an ever-expanding array of legally constituted phenomena around the entire globe (McCann 2016, xvi).

Of course, translating this all for law school audiences is no easy task. If legal scholarship and teaching were to embrace the full lesson to be learned, they would have to question fundamental assumptions and orientations. It would not be simply a matter of plucking isolated findings from social science studies, ${ }^{4}$ but a momentous shift toward a more sophisticated grasp of the epistemological and analytical contributions social science can make (McCann 2016, $\mathrm{xv}$ ). Lawyers trained with those frameworks in mind would be able to view law not just as abstract principles or strategic maneuvering, but as part of a wider sociocultural structure - as implicated in structures of power and meaning in non-random ways.

Now it may be that this project can never be successful - that any efforts at deep reconceptualization of legal scholarship and law teaching are doomed by the very structures of power and meaning that social science analyzes (Garth, this volume). Certainly, there is a risk of assimilation whenever social science scholarship seeks to engage with powerful systems like law (and the legal professionals administering, interpreting, creating, changing, or explaining it) (Sarat and Silbey 1988). On the other hand, as Bryant Garth (this volume) notes, "[o]ne achievement of NLR ... is a focus precisely on this tension and how translations take place", which can help open legal scholarship to a broader range, and higher quality of social science as well as helping social scientists better understand the perspective of law and lawyers. At the very least, it can name the problem of inadequate or incomplete translations, drawing attention to what is lost in the process.

Much ink has been spilled dissecting and arguing over the Legal Realist tradition - how to define it, what can be declared "in" or "out", who the legitimate heirs to the original US Legal Realists are (if there are any). A number of experts in jurisprudence have by now lined up in favor of escaping endless definitional debates, instead charting interesting ways forward (see, e.g., Bix 2016; Twining 2016; Tamanaha 2016; Dagan, Kreitner, and Kricheli-Katz 2018). William Twining has urged NLR to distinguish between the historical school of American Legal Realists (ALR) and a more generalized tradition of viewing law realistically (which he

4 James Boyd White, in his illuminating volume Justice as Translation, describes this as taking the "findings" of one field (say, a social science) and using those findings for another (say, law) - and suggests that such an approach falls short in part because such findings are "tentative conclusions in a series of tentative conclusions ... [a]nd even where a field does establish a particular view of the world, it does so only from its own point of view - its purposes and aims, its prior questions, and senses of method and this makes the simple translation of findings impossible" $(1990,13)$. 
refers to without capital letters as "legal realism") (2016, 128). In service of developing the broader Legal Realist tradition, he urges that "discussion of legal realism in respect of contemporary issues needs to break free from historical debates about ALR and its significance" (2016, 128). Along similar lines, Brian Tamanaha has recommended that "individuals identified as [original legal realists] should not be seen as a group whose views define realism, and second, realism is a complex of attitudes toward law that took hold at the turn of the twentieth century and continues to the present" (Tamanaha 2016, 164). As we will see, a number of chapters in this volume take up the historical heritage - not with an eye to definitional debates but as a way of rediscovering knowledge for today's NLR.

If the law-and-society tradition is one important bridge between an earlier realism and today's efforts, then NLR continues a longstanding attempt to help law professors view law "in action" as well as "in books", drawing on systematic knowledge from social science. At the same time, it seeks to educate social scientists about the "internal" legal view. With today's scholarly and legal worlds in mind, NLR has always insisted on a global perspective and on attention to inequalities of race, gender, class and other sociocultural divisions. It joins a number of scholarly efforts that share similar goals: global legal studies, area legal studies, empirical Critical Race Theory, intersectionality research in the social sciences, and others. And returning to our earlier discussion of ELS, as McCann (2016, xvi) explained:

NLR may distinguish its general orientation from ELS and [Law \& Economics], but [NLR] advocates have consistently reached out, welcomed, and engaged the latter in a host of ways, sometimes critical but always friendly. There is no reason to exaggerate conflict, when in fact there is a lot of vigorous, constructive engagement going on.

The core impulse is to cast a broad net in service of generating the best possible translations of social knowledge and law.

\section{STRUCTURE OF THIS VOLUME}

Thus our version of new Legal Realism is pluralistic. It recognizes the importance of historical, contextual, cultural, social, and normative approaches to understanding how law operates in action. We frown on the increasing capture of the term "empirical" by ELS as referring exclusively to quantitative studies of law that focus on empirical or psychological modes of analysis. New Legal Realism encompasses a broad array of quantitative and qualitative approaches to knowledge.

We believe the strength of this collection lies in its diversity of theories, methods, and intellectual roots. It brings together scholars from across the academy, including but not limited to law professors, historians, sociologists, anthropologists, political scientists, and psychologists, to name a few, whose work studies law and legal practice empirically; together they provide a compelling demonstration of how a new Legal Realist approach is able to inform our understanding of law in the world. The wide range of disciplinary and interdisciplinary perspectives combined with a display of multiple methodological approaches - including statistics, ethnography, historical analysis, interviews, experiments, and participatory research - allow for greater focus on issues of translation between law and empirical research. While individual chapters cover a wide range of topics including policing, prisons, immigrant rights, legal education, legal profession, human rights, constitutionalism, access to justice, and insurance, 
they are nested in theoretically-informed empirical understandings of legal institutions and the individuals and organizations that encounter law. In addition to these empirical foundations, some chapters, where appropriate, do explore the normative implications of their theoretically informed empirical findings. Consistent with the "big tent" frame of new Legal Realism, these scholars do not assume that their individual method is the only way of understanding a particular social or legal issue. Finally, this volume also includes contributions on how to better bring NLR perspectives into pedagogy and teaching in law schools and social science departments. Thus, we hope this volume highlights the powerful virtues of new Legal Realist research, as well as an appreciation and awareness of the challenges of translation between social science and law.

\section{Legal Realism Across Time and Place}

The first part of the volume, on the varieties of Legal Realism - then and now - provides a framework for the rest of the book by highlighting some of the main issues that have developed as the new Legal Realism field has matured from its earlier origins and reached out globally. These initial chapters provide a broad perspective on the roots and reach of new Legal Realism that encompasses the variety of perspectives that developed not just in different parts of the US, but also in Europe and the Global South. The opening "think piece" by Elizabeth Mertz, with Marc Galanter, challenges readers to think of today's NLR as a vibrant realization of aspirations expressed by original realists such as Karl Llewellyn, Soia Mentschikoff, and Jerome Frank. Current NLR scholars like Thomas Mitchell and Bernadette Atuahene combine legal theory, doctrinal analysis, social science research, social theory, law reform and attention to law in action, creating a synthesis never achieved by the original realists.

The next two chapters provide a unique perspective on the history of US Legal Realism, introducing a new division between "east coast" and "midwestern" roots that offers a corrective to traditional accounts. ${ }^{5}$ Laura Kalman, noted historian of Legal Realism, reviews the loose assemblage of scholars whose internecine battles led to the birth of a coherent East Coast "Realist" movement during the 1920s and 1930s in the US. Early skeptics of free market economics and accompanying myths such as the value-free "rational man", they legitimized the study of law's real impact in a way that outlived the original realists - sowing seeds that Kalman traces through the Legal Process, Law-and-Economics, Critical Legal Studies, and Law-and-Society movements (the last of these existing mostly outside of law schools). In the next chapter, Paul Baumgardner and Ajay Mehrotra deliver a pathbreaking account of Midwest Legal Realism, tracking its influence not only on the original East Coast realists, but also as a key site for the legacies of Legal Realism generally. Key moments in the founding of law-and-society, law-and-economics, and critical legal studies all share fascinating connections with the earlier Legal Realism, and those connections lead through midwestern law schools often overlooked in standard, elite-focused histories. The two historical chapters illustrate the NLR approach of combining top-down and bottom-up perspectives, and of taking seriously the social roots of ideas or intellectual movements.

The final two chapters of this part explore NLR not only over time but also across national boundaries, reaching to Europe and to parts of the Global South. Entering new realms brings

\footnotetext{
5 This recognition of the realists in the Midwest fits with growing interest in the area as a distinctive region often overlooked by historians (see Lauck 2013).
} 
new perspectives rooted in the histories and conditions of these different spaces. In their chapter on NLR in Europe, Holtermann and Madsen argue that European Legal Realism, both old and new, has a distinctly separate origin and focus when compared to Legal Realism in the US, even as it too sought to challenge legal formalism. Tracing its origins to the Sociology of Law first articulated by Eugen Ehrlich who identified the problem of law on the books versus law in action, Holtermann and Madsen argue that European Legal Realism takes a more legal-philosophical orientation and that European NLR seeks to develop an "epistemologically sound empirical legal science", and is less concerned with the more pragmatic and institutional orientation characteristic of NLR in the US. In contrast to the claim of a different form of Legal Realism in Europe, Huneeus and Klug survey socio-legal approaches to law in Africa and Latin America, noting that while there is a range of NLR-friendly scholarship in these parts of the Global South, "[T]here are no movements or schools of scholars in Latin America and Africa that identify themselves as writing in the NLR tradition". Instead, Huneeus and Klug argue that NLR scholars in the North may benefit from some of the NLR-friendly ideas that have emerged in southern scholarship, including the jurisprudence of indigenous rights as well as the debates over transformative constitutionalism.

Together these five chapters provide a rich, diverse, and historically grounded overview of New Legal Realism's origins and potential pathways. They also give a sense of the range of approaches to history and theory encompassed within NLR. Taking an important "top-down" approach, Laura Kalman tracks the more elite East-coast Legal Realists and their apparent heirs, while expressing some doubt about claiming such legacies. From a more "bottom-up" perspective, Baumgardner and Mehrotra look to the full range of personal histories and contexts beyond professional lives among those elites, finding strands of older and new realism throughout the often overlooked, less elite midwestern institutions. From one vantage, the aegis of realism is an elite prize over which competitors vie in seeking legitimation and status. From another, realist approaches are grounded in lives and institutions that have been omitted from official histories, but which actually provide some of the missing links in the story. Both accounts have validity, and both require us to consider the role of power and status in intellectual histories. A similar challenge arises from the call to consider quite different ideas about realistic studies of law emerging not from the US, but from Europe, Latin America, and Africa. Whether from within the tradition of European Legal Realism or from the emergence of new perspectives on indigenous rights and "transformative" constitutionalism in African and Latin America, it is clear that NLR in the US has and will continue to benefit from the realistic study of law globally. The recognition of NLR-friendly or -related work from outside of the US must of course also be integrated with the long tradition of law-and-society scholarship that has focused on the globalization of law, whether from William Twining or Eve Darian-Smith's global law in context perspectives, Lauren Benton's historical perspective on law and colonialism, or Sally Engle Merry's work on the translation of international human rights into local contexts. Finally, there is a long standing law-and-society literature on the role of lawyers in different societies that is central to any realist understanding of law.

\section{Social and Legal Dilemmas in Today's World}

Part II focuses on how Legal Realist scholarship meets current dilemmas. The chapters in this part wrestle with current challenges that face various parts of the world including policing, immigration, legal education, access to justice, and international law and judicialization of pol- 
itics. For the most part, the topics cut across political and geographical boundaries and reflect important issues facing the citizens and governments in a variety of parts of the world, casting light on common trends and context-based differences. The part as a whole illustrates how new Legal Realist approaches impact analysis and reform efforts in pressing social arenas. In each area, we bring together researchers using several different empirical approaches to demonstrate how new Legal Realism provides a meeting place where enlightening information from a variety of social science disciplines can come together to elucidate law. This part also demonstrates contemporary Legal Realism's ability to bridge both public and private domains. The studies in these chapters continue a commitment found from NLR's earliest publications: that our writings not just talk about the study of law in action, but perform (or integrate and use) that research, in interdisciplinary conversations that draw on multiple social science methods and theories - while also taking formal law seriously.

\section{A. Policing}

The first topic covered in this section is policing. These researchers examine how law works out when it "hits the ground" in the form of police interventions. Sebastian Sclofsky takes us to São Paulo through an ethnographic account of how residents in a peripheral area remain caught between two forms of law: the police representing formal power through acts of state-backed violence, and local gangs enforcing order through their own forms of violence. Although he is a political scientist, Sclofsky uses the close-up method of ethnographic observation more commonly found in anthropology, while asking questions informed by political science theories about law and the security state in capitalist systems. He sheds light on the way formal law can spur and interact with informal law, with unintended results that actually cede some kinds of power to non-state, sometimes violent, actors. Trained as a political scientist at Australian National University, Nick Cheesman has conducted long-term research that combines field observation and analysis of legal texts in Myanmar, with a focus on the rule of law and police misconduct. He argues that understanding the conditions that give rise to police torture requires the input of multiple methods and disciplines, and thoughtfully evokes NLR work on translation in pushing lawyers to consider what social science could offer on this important question. His engaging account of NLR's possibilities, and the example of his own work, invite deeper thought about how to accomplish multi-method, multi-disciplinary perspectives on pressing social problems. Psychologist L. Song Richardson and critical race theorist Devon Carbado write together in the final chapter of this section, which uses empirical, theoretical and historical research to uncover the problems that emerge in black-on-black policing. They demonstrate how a realist approach requires more sophisticated remedies for discrimination than simply diversifying workplaces; diversity needs to be accompanied by empirically informed understandings of the actual practices and pressures of specific workplaces. Their expert overview of psychological insights relevant to police bias gives a pointed and important example of just how this could work in the area of policing.

Despite different points of departure and areas of study, the three chapters converge in combining attention to formal law with deep empirical dives studying police practices on the ground, while also locating what they find within wider sociopolitical developments. Together they document the deeply rooted structural reasons why the line between legality and illegality becomes so difficult to maintain in policing. Combinations of internalized social hierarchies and the paradoxes of state-based power thwart efforts to restrain police abuses - and indeed often covertly encourage or even rely on those abuses. 


\section{B. Immigration}

Anthropologist Susan Coutin leads off this section with her provocative assertion that NLR should move toward undermining boundaries between law and social science, rather than just bridging between them. She recounts a collaborative effort between law and social science faculty specializing in immigration that launched both joint teaching and joint research endeavors. In a fascinating and detailed account of her fieldwork, she recounts how her data collection required her to engage with activist groups that had to respond to rapid legal changes with dramatic impacts on the lives of immigrants. While social scientists often discuss how getting "too close" to their subjects can create problems in data collection and analysis, they have not given enough attention to how too much distance can skew and even completely hide important data and observations. Leila Kawar and Jonathan Miaz's empirical study of what is happening when immigration policy is judicialized compares the understandings of the participants in each of three separate jurisdictions: the US, France and Switzerland. They demonstrate that contestation over immigration and asylum policy questions is a culturally productive process that engages not only courts and legislatures but also a range of other kinds of actors. Their study reveals how different legal cultures, institutions and practices produce different registers through which judicialized immigration politics are enacted in different jurisdictions. Kawar and Miaz demonstrate why empirical investigation of what judicial intervention means to administrators and advocates who are invested in these cases is essential to understanding the different registers - whether adversarial, instructive and formalistic, or through competing assertions of expertise - adopted by participants in these cases.

In the final chapter of this section Sara McKinnon argues that pairing NLR with the discursive tools of rhetoric brings an understanding of messages and meaning making at the ground level, and shows how these trickle up to shape the discursive milieu where immigration and refugee policy and law are developed and enacted. McKinnon explores the discursive history of the refugee management system and demonstrates that cis-gender women generally only receive refugee status and protection as relational and private subjects. She identifies three conventions that guide immigration judges' evaluation of credibility in US asylum claims good speech, narrative rationality and embodied emotion - and argues that revealing how such terms, definitions, arguments and evidence are in legal reasoning and decisions in the service of maintaining, strengthening, contesting, or changing societal power relations, will allow scholars and practitioners to work with the constraints of those discursive legacies to create greater potential for access to recognition and justice.

These three chapters converge on a deeper insight into how the language of immigration law reflects and responds to culture and power, opening new conceptual vistas for those interested in maintaining epistemological and methodological rigor while also taking responsible and responsive stances on translating social science in the real world of law.

\section{Legal education}

The chapter by Susan Coutin already described an NLR venture that used a shared interest in immigration to bring lawyers and anthropologists together both in the classroom and in the field, defying traditional boundaries in multiple ways. This section brings us more such accounts, examining the revolutionary potential of NLR in challenging standard practices in legal education. Emily Taylor-Poppe undertakes a searching examination of the barriers to incorporating NLR - and empirical work generally - into US law school teaching. She argues that NLR scholars have placed "the burden of translation" too much on the empiricists, whether 
qualitative or quantitative - arguing instead the lawyers will need to develop competencies in empirical methods for this translation to succeed. She then offers compelling examples of how incorporating empirical research on teaching itself could be part of an NLR strategy in law schools, along with integrating training on empirical methods and research - using examples from her own teaching of civil procedure. Mansfield and Mertz give an in-depth example of how they combined clinical and social science training for a group of family law students, drawing a direct connection between their efforts and the vision for legal education reform outlined by Jerome Frank, one of the original Legal Realists. The students created practical "products" using hands-on, "bottom-up" research, technical knowledge of legal doctrine, and clinical training. This effort, while it helped to shift Taylor-Poppe's "burden of translation", did not address structural resistance to reform. In the next chapter, Louise Victoria Johansen and Anne Lise Kjær take us to Denmark to examine a similar resistance to attempted reforms of legal education. Using documents produced as part of reform efforts, interviews with key players, and their pilot study of Danish law students, Johansen and Kjær also take account of wider sociopolitical context of legal education. Although the developments in Denmark unquestionably bear the mark of distinct national debates, there is also much that will be familiar to scholars tracking worldwide trends regarding legal education reform: perennial claims of crisis, calls for major reform, quiet resistance from within the academy, resulting changes that are incremental at best. Tackling a similar phenomenon - but this time examining intersectional discrimination by race and gender in the US legal academy - Meera Deo's research has used a combination of qualitative and quantitative methods to map the stubborn tenacity of racism and sexism in impacting legal education. Her contribution to this volume offers a deeply thoughtful comparison of NLR with the empirical Critical Race Theory (eCRT) movement, using her own and others' empirical research on the state of racism in the legal academy as a touchstone. She concludes with both a challenge and a hopeful prescription for NLR, urging more integration of eCRT within NLR.

These chapters on legal education continue the longstanding NLR interest in studying and changing how law schools train lawyers (Aiken and Shalleck 2016; Erlanger et al. 2005; Mertz and Barnes 2016; Southworth, Garth, and Fisk 2016; Tejani 2016; Trubek 2005). They also take inspiration from the legal education reform aspirations of original US Legal Realists such as Jerome Frank. Now we can add generations of work in clinical legal education as well as research on education generally - and legal education in particular - all pointing to a complex integrated approach where social science and clinical training can help each other transform the law school classroom.

\section{International law, global standards, and regime change}

The chapters in this section consider how NLR perspectives and methods may throw new light on global developments whether it is the prevalence of indicators, the practice of new forms of global justice or comparative understandings of judicial authority. These three chapters also demonstrate different methodological strategies and critiques that NLR embraces and provides examples of their application in the global context.

In their chapter on the uses and abuses of global social indicators David Nelkin and Mathias Siems explore how indicators, increasingly used to measure and monitor a wide range of key social issues, "do not only provide evidence for decision making" but also "claim and constitute authority". Their study identifies three forms of indicators - explanatory, policy and ranking indicators - and ask "what, if anything, differentiates indicators from other forms of 
ordering and regulation". Finally, they note that for NLR, which is "interested in the translation of social science into law, indicators can offer an intriguing illustration of the way facts are turned into standards and standards into facts". The second chapter by Jens Meierhenrich and Richard Wilson demonstrates how the application of ethnography, a qualitative method central to NLR, provides new insights into the law and practices of international criminal tribunals. Critiquing standard approaches to international criminal law, which either focus on establishing a body of formal legal doctrine or are rooted in traditional empiricism, which provide only a limited understanding of the practice of international criminal law, Meierhenrich and Wilson argue that their approach "seeks to bring practice and legal reasoning in closer dialogue with one another, in order to comprehend how the daily procedures of courts and the embedded assumptions of prosecutors, judges and defense counsel influence concrete legal outcomes". Their study, they argue, provides a normative basis for opposing arid formalism and offers a realistic assessment of what can be achieved in the realm of international law. This fostering of a "clear-eyed assessment of both the successes and shortcomings of international justice institutions they attribute to the "methods and theories encouraged by New Legal Realism'". In the final chapter in this section Heinz Klug adopts yet another strategy within the NLR repertoire to question the argument that the rise of constitutionalism in the late twentieth century is producing a judicialization of politics. While taking the social science seriously Klug explores the different sources of juridical power and questions whether the assumptions that have been made about the rise of a "juristocracy" are supported when counterposed by the realist limits of judicial authority in society. From this perspective Klug argues that NLR's insistence on recognizing the internal dimensions of the law, including the sources and limits of its authority, provides an important means of evaluating empirical and theoretical claims about the capacity, authority and legitimacy of legal institutions.

\section{E. Accessing justice through law}

Another longstanding core theme for NLR has been using empirical methods to study how law succeeds or fails in providing justice to people from across a wide spectrum of society including those who have been marginalized (see, e.g., Luna 2005; Mitchell 2005; Pager 2005; Nielsen and Nelson 2005). Of course, lawyers and judges and other legal professionals are a key link in the provision of justice - and so NLR has also from the beginning focused on the legal profession and legal education. But this focus also has led researchers to ask about the other professionals and laypeople - and institutions - involved in the delivery of law. In addition to demonstrating the continued interest in these kinds of research interests within NLR, the chapters in this section exemplify the movement's pragmatist orientation to developing theories about law through empirical research - the theory grows in and through the doing of that research.

The first chapter in this section by Liora Israël examines the question of accessing justice through a case study involving a "movement" lawyer representing LGBTQ+ clients at many levels in France. In a set of ethnographic accounts that help us understand forms of legal mobilization and strategy as they impact clients "on the ground", Israël takes us from a lawyer's initial meeting with clients, through a court hearing, to the lawyers' handling of a major European Court of Human Rights decision involving her own clients. If Israël's close ethnography shows us how individual lawyers struggle at multiple levels to open up the legal system for traditional excluded groups, Rebecca Sanderfur's chapter gives us a panoramic view of research on access to civil justice in the US and the landscape it reveals. She organizes 
the rich array of research ranging from large-scale quantitative to small, in-depth qualitative studies along lines familiar to Legal Realists: she distinguishes research focused on (1) law on the books and access to process; (2) law on the books and access to outcomes; (3) law in action and access to process; and (4) law in action and access to outcomes. Her framework challenges accepted wisdom and highlights important areas that haven't received the attention they deserve. In the following chapter, Shauhin Talesh uses the insurance field as a pathway for exploring how insurance institutions shape law in formal and informal settings, with the key being the application of a risk-based logic that serves as a means through which insurers, as legal intermediaries, shape and influence law and legal institutions and impact access to justice. Talesh identifies and explores different contexts in which this plays out, including: how insurance exerts a regulatory force over its subjects and acts as a form of governance beyond the state; how the presence of liability insurance often shapes how civil lawsuits are structured; how risk assessment and actuarial techniques increasingly are used to categorize criminals with varying degrees of dangerousness; how risk management now permeates and influences how many judges operate in various problem-solving courts; and finally, he identifies the processes and mechanisms through which insurer risk management techniques influence how organizations understand law and compliance. Using this focus on risk, Talesh demonstrates how NLR inspired multi- and interdisciplinary, theoretically informed research, may serve to translate social science for lawyers. Taken together, these three chapters show the role of individual lawyers, of wider social and legal systems, and of institutions on access to justice.

The next two chapters examine law's impact on rural and urban property systems that differentially disadvantage poor, and often minoritized, landowners. Thomas Mitchell's chapter highlights the failure of legal and other researchers to pay significant attention to rural America and especially how law and policy is impacting African Americans and other people of color in this space. Mitchell argues that a NLR lens will bring greater attention to the effects of existing law and policy on these communities in rural areas as well as reveal a far more accurate picture of property relations in these rural communities, free from the distorting lens of powerful rural stereotypes and myths. Interestingly, this refocused lens also yields better results for white rural landowners. Lisa Alexander's chapter is a quintessential example of the power of NLR approaches, combining detailed technical knowledge of the law with in-depth understanding of the actual lived situations of homeowners and renters in US cities as the Coronoavirus pandemic hit. Her resulting analysis uncovers the many double binds built into responses to the crisis, which has only exacerbated and spotlighted how existing legal, social, political and economic structures limit true access to a supposed system of civil justice.

These chapters collectively offer a series of mechanisms, processes, and variables to help explain both the social problems that are explored but also how one might go about reforming or improving social outcomes.

\section{New Legal Realism Across the Disciplines}

Finally, Part III, titled "Disciplinary Perspectives", illustrates how disciplinary approaches inform new Legal Realist approaches to law. These chapters approach new Legal Realism from the perspective of various disciplines, with an eye toward trying to help illuminate how disciplinary approaches can help better translate law and social science to diverse audiences. Contributors to this last part articulate different disciplinary approaches toward tackling legal 
questions and problems and also offer guidance on how one translates those perspectives to legal audiences. These chapters do not shy away from addressing both legal doctrine and problems that arise in legal practice. In doing so, these new Legal Realist perspectives we hope foster a growing dialogue between scholars working in law schools and social science departments.

The first chapter, by lawyer-anthropologist Riaz Tejani, begins with a compelling review of the history of anthropology up until the present day. He sets this history and a deep understanding of what the field has to offer law in contrast with a shallow, uninformed legal reading of ethnographic methods, performed without adequate "expert" or insider knowledge of the topic. By contrast, Tejani - an "insider" in both law and anthropology - carefully parses the way anthropological method and inquiry parallel legal realist concerns. At the same time, he indicates how anthropological expertise in questioning unexamined assumptions could be helpful to law.

Calvin Morrill and Lauren Edelman explore the relationship between the Sociology of Law and New Legal Realism by first tracing the emergence of the Sociology of Law from the great social theorists of the nineteenth century. In contrast to these more theoretical origins, they argue that sociological jurisprudence and Legal Realism emerged in the context of the progressive era and brought an empirical focus to case law. While this empirical focus did not manage to gain traction in the law schools, Morrill and Edelman argue that "these two paths came together in the early law-and-society movement, which greatly influenced and overlapped with the Sociology of Law". While arguing that "the Sociology of Law, law-and-society scholarship, and NLR are complementary and overlapping" Morrill and Edelman acknowledge that NLR has a distinctive mission, to break down barriers between law and social science by "translating social science findings in a way that can inform legal scholars and the law itself". They also identify important distinctions between law, which they note is organized around individual rights and responsibilities, and sociological explanations which look beyond individuals to patterns that exist at the level of societies or at intermediate levels within a society. Finally Morrill and Edelman conclude that legal analysis would be richer "to the extent that NLR can bring the insights of sociology into the law school world".

In the following chapter explicating political science approaches, Jeb Barnes explores how a New Legal Realism may be able to address existing limitations in the study of judicial behavior. Barnes suggests adopting an NLR type analysis that avoids both the positivist and substantive dilemmas that he argues dominate the political science literature. His approach would avoid the positivist dilemma "by treating the law and courts as a particular institutional setting (as opposed to a set of formal commands) and the substantive dilemma by assessing how more legalistic policy regimes engender distinct administrative, political and social trade-offs". For Barnes, the benefit is that such an NLR strategy, which would include both qualitative and quantitative analysis as well as observational and experimental methods, would also "invite multiple and mixed-methods scholars to contribute to our understanding of how and why the law matters in politics and policy-making, whether these scholars happen to be in political science departments or law schools".

Highlighting NLR's receptiveness to a broad range of social science methods, Tom Tyler's chapter reviews how psychologists have approached the study of "the way that law and legal authorities function in the real world". In particular, he explains the way psychologists have used experimental methods to examine empirically how legal decision-making works - while also remaining receptive to findings from studies using different methodologies. Tyler also 
stresses the importance of theory in guiding empirical research on psychology and law. He uses examples of psychological research touching a variety of legal concerns such as eyewitnesses, interrogations and confessions, judgments and decision-making, and more. In each of these areas, Tyler demonstrates how empirical research can provide a corrective to naïve intuitions that have shaped law.

In her extraordinary chapter on how history may or may not be of use to New Legal Realism, Sara Seo explores the relationship between history and our understandings of law and legal change. Seo points out that insights may be gained by historical accounts of significant cases so long as we see them "less as landmarks but more as points in time" and that the "experiences of people on the ground can throw new light on well-established accounts" of both law's decline and progress. She then asks, "[s]o what do we do with this historical knowledge?" and answers that a "common lesson in these works is the need for humility about law's potential in solving society's problems". Seo concludes that since "stories are fundamental to how humans process the social world", the storytelling of historians explains how things came to be and their identification of problems and their origins is the "crucial first step to figuring out what to do next". ${ }^{6}$

Like legal history, jurisprudence is a field that is well-accepted within the legal academy, though it has yet to seriously incorporate the original realists' insights or the decades of sociolegal research bearing on those insights that have appeared since that time. Brian Bix is known for his scholarship not only in jurisprudence, but also in family and contract law from vantages that take sociolegal research seriously. ${ }^{7}$ In his chapter for this volume, Bix explores the marginalization of realist thought in dominant schools of jurisprudence and legal theory, concluding that better communication between NLR and jurisprudence would "benefit both sides".

If Bix examines jurisprudence as a way of defining legal scholarship from the inside, the volume concludes with a chapter by Bryant Garth on law as a discipline examined from a more sociological point of view. He contrasts developments in Europe with those in the US, recounting a history in which lawyers and the law have arguably played a more important role vis-à-vis the state in the US. Based on this foundation, he traces successive generations of social scientists whose work on law became subordinated to the perspectives and demands of law and lawyers - who wielded formalism and realism alike to stay in powerful roles vis-à-vis the state. He contrasts with this the medieval revival of Roman law, the weakness of legal theory vis-à-vis the practicing bar in Great Britain, and German legal science from Bologna through the present - in each case connecting state power, the role of the legal profession, and developments in legal theory. While sounding a skeptical note about overcoming the dominance of legal thought in translations of social science, Garth does offer some notes of optimism.

In this breathtaking array of disciplinary perspectives, we see how NLR can provide a meeting point rarely found in other academic discourses - a meeting point where a shared

\footnotetext{
6 It may be no accident that another advocate of storytelling as an NLR legal method is historian Robert Gordon (2016).

7 Notably, Bix has engaged with "relational contract" theory, a form of contract theory that builds in consideration of social relationships in much the way Llewellyn and Mentschikoff attempted to do with the UCC. Stewart Macaulay, a founding member of both law-and-society and NLR, is also one of the key founders of relational contract theory.
} 
concern with law in action, alongside respect for law as its own discipline, permit scholars who might otherwise never talk to engage in productive "triangulation" of their findings and methods regarding law in general, and also particular areas of law.

\section{CONCLUSION}

We were honored to work with the gifted group that joined in this project. They have ably demonstrated that the breadth of NLR does not indicate a lack of depth. To the contrary, in each arena it touches, this work pushes us to think more deeply about how law in books and law in action are implicated in one another and in deeper questions of justice and society. NLR's commitment to interdisciplinary investigations entails a willingness to engage in debate - because disciplinary divisions so often involve differences in method, epistemology, what work or perspective is valued, and how we view the academic enterprise itself. For example, while most of the scholars involved in this volume comfortably find their roots in an ongoing broader realist tradition, a few remain ambivalent about claiming that legacy. There is room within this tent for internal questioning and critique; that is one of its strengths. At the same time, there is broad agreement that the enterprise itself should not founder on endless definitional debates (as, arguably, discussions of the original American Legal Realists too often have). This is in keeping with the doubly pragmatic orientation of NLR, which remains focused on achieving the most accurate possible empirical accounts of how law operates (and fails to operate) - and on making legal scholarship more accountable to the public that law is supposedly serving.

Another point on which our contributors vary, interestingly, is how they build on proposed definitions and theories for NLR. In keeping with early calls for pragmatist orientations in NLR, these scholars build their shared realist project by putting theory to use in tackling legal issues of common interest. ${ }^{8}$ An unexpected strength of this particular collection, in our view, is the way it brings that vision to fruition - somehow building a scholarly community around shared strands of consensus while allowing the exigencies of a topic or approach free rein. NLR scholars are free to decide what the best method is for studying and addressing particular problem areas - and to grow the theory guiding them from the "bottom-up" as well as from the "top-down". A powerful payoff for NLR here is that the loose but still meaningful definitional threads that draw these scholars together allow for an exciting kind of shared learning - where neither disciplinary perspective nor research topic area limit them from working together on difficult issues of translation between law and social science. ${ }^{9}$

In sum, we hope this volume highlights the evolving history of new Legal Realism from a variety of perspectives, shows how those anchored in new Legal Realist approaches impact analysis and reform efforts in pressing social areas, and demonstrates how various disciplines inform new Legal Realist approaches to law. We also believe this volume offers a clear

8 Examples of early calls within NLR for pragmatist methods and orientations include Erlanger et al. (2005); Nourse and Shaffer (2009); Tamanaha (1997).

9 The "big tent" form of NLR has explicitly made room for a variety of approaches to epistemology, and for mutual conversation on issues of knowledge production - a trait which legal philosopher William Twining views as a major asset (Twining 2016). It is worth pointing out that there is a possible congruence between some parts of NLR and Ian Shapiro's version of epistemological realism (Shapiro 2009). 
and sharp contrast to the ELS approaches to law that are currently rivals for attention and dominance in law schools - an NLR that is multi-disciplinary, open to mixed methods, and most-importantly, focused on theoretically-informed research. It goes without saying that this NLR commitment rejects attempts to limit the meaning of "empirical" to quantitative research, or to limit the means and ends of empirical research to formal hypothesis testing and the forms of causal analysis that are particular to quantitative models. While there is certainly room for these methods of analysis within NLR's broad tent, we think the empirical information to be gathered and analyzed would be impoverished in serious ways were we to limit inquiry to such a narrow enterprise. Well-respected quantitative and experimental researchers from the law-and-society and other traditions have long acknowledged the higher standard that they can achieve when they incorporate grounded observational and other qualitative research in their formulation of questions to ask, their approaches to surveys or experiments, and much more (see Tyler, this volume).

Crossing and drawing on fields and methods - and combining their efforts through interdisciplinary conversation and research, the contributors to this volume demonstrate how the study of law may be advanced by actively embracing the new Legal Realist approach. Consistent with prior volumes on new legal realist thinking (Klug and Merry 2016; Mertz, Ford, and Matoesian 2016; Mertz, Macaulay, and Mitchell 2016), there is no attempt to claim that one approach is superior over another. Instead, we recognize the challenges of translating economic, social, and political contexts by different disciplinary methodologies into an understanding of law. By focusing on translation between social science and law, new realist perspectives on the study of law contribute to the broader law-and-society movement from which new Legal Realism sprouted.

\section{REFERENCES}

Aiken, J., and Shalleck, A. 2016. Putting the "Real World" into Traditional Classroom Teaching. In Mertz, E., Macaulay, S., and Mitchell, T.W. (eds) The New Legal Realism: Translating Law-and-Society for Today's Legal Practice, Volume 1, 51-73. New York: Cambridge University Press.

Bix, B. 2016. Doctrine, Data, and High Theory. UC Irvine Law Review 6: 137-147.

Dagan, H., Kreitner, R., and Kricheli-Katz, T. 2018. Legal Theory for Legal Empiricists. Law \& Social Inquiry 43: 292-318.

Du Bois, W.E.B. 1899. [1995] The Philadelphia Negro: A Social Study. Philadelphia: University of Pennsylvania Press.

Durkheim, E. 1893 [1984]. The Division of Labor in Society. New York: Free Press.

Eisenberg, T. 2004. Why Do Empirical Legal Scholarship? San Diego Law Review 41: 1741-1746.

Erlanger, H., Garth, B., Larson, J., Mertz, E., Nourse, V., and Wilkins, D. 2005. Is It Time for a New Legal Realism? Wisconsin Law Review 2005: 335-363.

Garth, B. 2021. Law as a Discipline: Legal Theory, Interdisciplinary Legal Theory, and Ways of Speaking Legitimacy to Power. In Talesh, S.A., Klug, H., and Mertz, E. (eds) Research Handbook on Modern Legal Realism. Cheltenham, UK: Edward Elgar Publishing.

George, T.E. 2006. An Empirical Study of Empirical Legal Scholarship: The Top Law Schools. Indiana Law Journal 81: 141-170.

Gordon, R.W. 2016. Legal Storytelling as a Variety of Legal Realism. In Mertz, E., Macaulay, S., and Mitchell, T.W. (eds) The New Legal Realism: Translating Law-and-Society for Today's Legal Practice, Volume 1, 169-179. New York: Cambridge University Press.

Heise, M. 2002. The Past, Present, and Future of Empirical and Experimental Legal Scholarship: Judicial Decisionmaking as a Case Study. University of Illinois Law Review 4: 819-50. 
Klug, H., and Merry, S.E. (eds) 2016. The New Legal Realism: Studying Law Globally, Volume 2. New York: Cambridge University Press.

Lauck, J. 2013. The Lost Region: Toward a Revival of Midwestern History. Ames, IA: University of Iowa Press.

Luna, G. 2005. Legal Realism and the Treaty of Guadalupe Hidalgo - A Fractionalized Legal Template. Wisconsin Law Review 2005: 519-555.

Macaulay, S. 2005. The New versus the Old Legal Realism: "Things ain't what they used to be." Wisconsin Law Review 2005: 365-403.

Malinowski, B. 1959. Crime and Custom in Savage Society. Paterson, NJ: Littlefield, Adams.

McCann, M. 2016. Preface. In Mertz, E., Macaulay, S., and Mitchell, T.W. (eds) The New Legal Realism: Translating Law-and-Society for Today's Legal Practice, Volume 1, xiii-xxi. New York: Cambridge University Press.

Mertz, E., and Barnes, K. 2016. Combining Methods for a New Synthesis in Law and Empirical Research. In Mertz, E., Macaulay, S., and Mitchell, T. (eds) The New Legal Realism: Translating Law-and-Society for Today's Legal Practice, Volume 1, 180-200. New York: Cambridge University Press.

Mertz, E., Ford, W.K., and Matoesian, G. (eds) 2016. Translating the Social World for Law: Linguistic Tools for a New Legal Realism. New York: Oxford University Press.

Mertz, E., Macaulay, S., Mitchell, T.W. (eds) 2016. The New Legal Realism: Translating Law-and-Society for Today's Legal Practice, Volume 1, New York: Cambridge University Press.

Mitchell, T.W. 2005 Destabilizing the Normalization of Rural Black Land Loss: A Critical Role for Legal Empiricism. Wisconsin Law Review 2005: 557-615.

Nielsen, L.B., and Nelson, R. 2005. Rights Realized? An Empirical Analysis of Employment Discrimination Litigation as a Claiming System. Wisconsin Law Review 2005: 663-711.

Nourse, V., and Shaffer, G. 2009. Varieties of New Legal Realism: Can a New World Order Prompt a New Legal Theory? Cornell Law Review 95: 61-137.

Pager, D. 2005. Race, Crime, and Getting a Job. Wisconsin Law Review 2005: 617-662.

Sarat, A., and Silbey, S. 1988. The Pull of the Policy Audience. Law \& Policy 10: 97-166.

Schlegel, J.H. 1995. American Legal Realism and Social Science. Chapel Hill: University of North Carolina Press.

Shapiro, I. 2009. The Flight from Reality in the Human Sciences. Princeton: Princeton University Press.

Southworth, A., Garth, B., and Fisk, C. 2016. Some Realism about Realism in Teaching About the Legal Profession. In Mertz, E., Macaulay, S., and Mitchell, T.W. (eds) The New Legal Realism: Translating Law-and-Society for Today's Legal Practice, Volume 1, 74-94. New York: Cambridge University Press.

Suchman, M., and Mertz, E. 2010. Toward a New Legal Empiricism: Empirical Legal Studies and New Legal Realism. Annual Review of Law and Social Science 6: 555-579.

Tamanaha, B. 1997. Realistic Socio-Legal Theory. Oxford: Oxford University Press.

Tamanaha, B. 2016. Legal Realism in Context. In Mertz, E., Macaulay, S., and Mitchell, T.W. (eds) The New Legal Realism: Translating Law-and-Society for Today's Legal Practice, Volume 1, 147-168. New York: Cambridge University Press.

Tejani, R. 2016. "Fielding" Legal Realism: Law Students as Participant-Observers? In Mertz, E., Macaulay, S., and Mitchell, T.W. (eds) The New Legal Realism: Translating Law-and-Society for Today's Legal Practice, Volume 1, 95-118. New York: Cambridge University Press.

Tomlins, C. 2006. In This Issue. Law \& Social Inquiry 31: 795-796.

Trubek, L. 2005. Crossing Boundaries: Legal Education and the Challenge of the "New Public Interest Law". Wisconsin Law Review 2005: 455-478.

Twining, W. 2016. Legal R/realism and Jurisprudence: Ten Theses. In Mertz, E., Macaulay, S., and Mitchell, T. (eds) The New Legal Realism: Translating Law-and-Society for Today's Legal Practice, Volume 1, 121-146. New York: Cambridge University Press.

Weber, M. 1922 [1978]. Economy and Society: An Outline of Interpretative Sociology. Edited by G. Roth and C. Wittich, 2 Vols. Berkeley: University of California Press.

White, J.B. 1990. Justice as Translation: An Essay in Cultural and Legal Criticism. Chicago: University of Chicago Press. 